\title{
Editorial: Science and Environmental Journalism: Trends, Boundaries, and Opportunities for a Rapidly Evolving Industry
}

\author{
Hollie Smith $^{1 *}$ and Bridie McGreavy ${ }^{2}$ \\ ${ }^{1}$ Media Center for Science and Technology, University of Oregon, Eugene, OR, United States, ${ }^{2}$ Department of \\ Communication and Journalism, University of Maine, Orono, ME, United States
}

Keywords: science communication, environmental journalism, journalism, education, media

\section{Editorial on the Research Topic}

Science and Environmental Journalism: Trends, Boundaries, and Opportunities for a Rapidly Evolving Industry

Science and environmental journalism is entering a new era defined by increasing urgency in the face of climate change, politicization of science, and socio-political polarization across the globe. The evolution of the journalism industry has placed increasing demands on news organizations to do more with less in a rapidly evolving news environment, and we are only just now beginning to understand what this means for in-depth scientific and environmental reporting. Parallel to the shift to online news consumption, several news organizations have been forced to reassign specialty science reporters to a general assignment or eliminate the science desk completely in an effort to

OPEN ACCESS

Edited and reviewed by: Tarla Rai Peterson The University of Texas at El Paso, United States

*Correspondence: Hollie Smith hollies@uoregon.edu

Specialty section This article was submitted to Science and Environmental

Communication

a section of the journal

Frontiers in Communication

Received: 13 June 2018

Accepted: 25 June 2018

Published: 11 July 2018

Citation:

Smith H and McGreavy B (2018) Editorial: Science and Environmental Journalism: Trends, Boundaries, and Opportunities for a Rapidly Evolving Industry. Front. Commun. 3:31. doi: 10.3389/fcomm.2018.00031 stay competitive on smaller budgets. It is critical to understand what effects these dramatic shifts in the news industry have had on journalists' science writing, journalism education, and audiences' consumption of science news.

In this collection of original research articles and professional perspectives, we bring together the viewpoints of researchers who study changes in the journalism field and practitioners who are living those changes in their day-to-day lives. We asked contributors to submit research articles and essays that document and ask critical questions about trends, opportunities, and possibilities in environmental and science journalism, the effects of new media environments on science reporting and journalism education, and/or audiences' interactions with science journalism.

Takahashi and Parks set the stage by outlining five competencies of knowledge-based journalism and highlighting how those might be idealized when the changing media industry in the U.S. disproportionately emphasizes skills training and experiential learning. Takahashi and Parks outline the complexities of creating curricula that is flexible to respond to the changing demands of the media marketplace. Suldovsky et al. turn to newspaper coverage of localized risks and describe the effects of routine approaches to news reporting in the state of Maine. Together, these essays show how established research methods such as media content analysis can help identify changing trends of environmental journalism at local and global scales.

Three pieces in this topic highlight the voices of practitioners and educators in the field of environmental and science journalism. Menezes highlights how lean newsrooms have facilitated journalists becoming generalists, and how external training programs are trying to correct the field to a situation in which professionals can discern and disseminate accurate scientific information about the complex scientific issues. Hayden and Hayden provide a comprehensive overview of the changes in both the practices of science and journalism, and offer potential avenues for strengthening each in the next decade. 
Schmitt outlines how public science communicators can better communicate with news media professionals through push and pull techniques and advocates for specific pull-related strategies to enhance the role of science in news media, such as conducting informal assessments of the type of information public audiences most need at any given time.

These five pieces offer diverse insights into how the field of journalism is evolving, and how academics and practitioners can maintain relevance in the midst of a rapidly changing industry and world. As editors of this issue, we hope these pieces inspire questions, paths forward, and new understandings of how to the study and practice of journalism can enhance societal understandings of scientific and environmental issues.

\section{AUTHOR CONTRIBUTIONS}

All authors listed have made a substantial, direct and intellectual contribution to the work, and approved it for publication.

Conflict of Interest Statement: The authors declare that the research was conducted in the absence of any commercial or financial relationships that could be construed as a potential conflict of interest.

Copyright $\odot 2018$ Smith and McGreavy. This is an open-access article distributed under the terms of the Creative Commons Attribution License (CC BY). The use, distribution or reproduction in other forums is permitted, provided the original author(s) and the copyright owner(s) are credited and that the original publication in this journal is cited, in accordance with accepted academic practice. No use, distribution or reproduction is permitted which does not comply with these terms. 